\title{
PETRO-PHYSICAL CHARACTERIZATION OF "MADISON" FIELD, ONSHORE NIGER DELTA, NIGERIA
}

\author{
Olisa Benson Akinbode and Aduloju Bolakale Babatunde \\ Department of Applied Geophysics, \\ The Federal University of Technology, Akure, Nigeria. \\ (bensonolisa@gmail.com) \\ DOI: $10.31364 /$ SCIRJ/v8.i9.2020.P0920803 \\ http://dx.doi.org/10.31364/SCIRJ/v8.i9.2020.P0920803
}

\begin{abstract}
This report presents results of a study conducted to determine and evaluate the petro-physical properties of "MADISON" oil field, Niger delta with a view to understand their effects on the reservoirs hydrocarbon prospect and oil productivity of the field. The evaluated properties include porosity, permeability, fluid saturation, net / gross thickness and mobility which are all inferred from geophysical wire-line logs. A suite of wire-line logs comprising of gamma ray, resistivity, neutron and density logs for four wells from 'MADISON' oil field were analyzed for reservoir characterization of the field, but only two of the four wells possess the desired logs. The analyses carried out involve delineation of lithologies, identification of reservoirs and fluid types, wells correlation and determination of petro-physical parameters of identified reservoirs. Six reservoirs namely: A, B, C, D, E and F were delineated with their tops and bases at depth from $1902.96 \mathrm{~m}$ to $2389.02 \mathrm{~m}$. Their analysis indicates the presence of hydrocarbon in all the reservoirs. Computed petro-physical parameters across the reservoirs gave porosity as ranging from $25.2 \%$ to $29.7 \%$; permeability $2664.89 \mathrm{md}$ to 10184.26md and average hydrocarbon saturation of $82.85 \%, 81.05 \%, 76 \%, \quad 71.85 \%, 74.95 \%$ and $56.9 \%$ reservoir A, B, C, D, E and $\mathrm{F}$ respectively. These results together with the determined movable hydrocarbon index (OMI) values (0.238 to 0.515$)$ of the reservoir units suggest high hydrocarbon potential and a reservoir system whose performance is considered satisfactory for hydrocarbon production.
\end{abstract}

Keywords: Niger-Delta, Petro-physical, Wireline-logs, Porosity, Permeability

\section{Introduction}

Many forms of heterogeneity in rock properties are present in clastic petroleum reservoirs. Understanding the form and spatial distribution of these heterogeneities is important in petroleum reservoir evaluation. Porosity, permeability and fluid saturation are the key variables for characterizing a reservoir in order to estimate the volume of hydrocarbons and their flow patterns to optimize production of a field. Though petro-physical data are not completely obtained from undisturbed rocks, they provide information near the natural 
situation since the measurements are taken in-situ. Therefore, the use of wire-line geophysical logs in the estimation of physical properties of rocks provide good vertical resolution and detailed information about the formation or beds intersected by a given well, thus it can be applied in the estimation of porosity, permeability, fluid content and saturation determination, and other properties that are of interest.

The application of this technology to the Niger Delta has aided the understanding of the petroleum system within the province. Also, it has led to the design of better production and recovery plans by the oil and gas operators that have in turn given them value for their heavy investments. This study is intended to identify and duly characterize the reservoir unit(s) within the study area by the analysis of wire-line well $\log$.

\section{Geology of the study area}

The study area is an onshore field located in Niger Delta. Since the precise location of the study is unidentified (in order to ensure confidentiality of information), the general geology of Niger Delta is adopted for this study. The Niger Delta is located in the Gulf of Guinea and extends throughout the Niger Delta province as defined by Klett et al, (1997). From the Eocene to the present, the delta has prograded southwestward, forming depobelts that represent the most active portion of the delta at each stage of its development (Doust and Omatsola, 1990).
Exploration activities began in the Niger Delta since 1908 and have been intensified over the years as the demand for petroleum increases. The tertiary Niger Delta (Akata-Agbada) is the only petroleum system within the Niger Delta provinces, having its maximum extent of the petroleum system coincide with the boundaries of the province, while the minimum extent of the system is defined by the areal extent of fields (Tuttle et al, 1999).

\section{Aim and Objectives}

The aim of this study is to delineate the economic reservoir unit(s) within the lithologic sequence of the field study. The objectives of the study include:

- Identification of the different lithologic unit(s) within the sequence of the study area

- Identification of the reservoir unit(s)

- $\quad$ Estimation of the petro-physical parameters of the reservoir rock, such as porosity, permeability, fluid content and thickness.

- Definition of the reservoir geometry by means of well to well correlation.

\section{Study location}

www.scirj.org

(C) 2020, Scientific Research Journal

http://dx.doi.org/10.31364/SCIRJ/v8.i9.2020.P0920803

This publication is licensed under Creative Commons Attribution CC BY. 


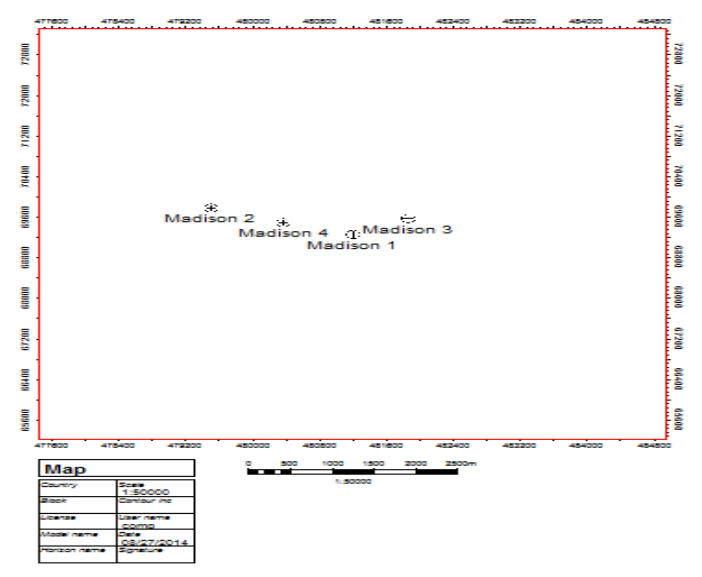

Figure 1: Base map of the study area.

Figure 1 shows the basemap of the study area.

\section{Problem definition}

Traditionally reservoir properties were determined by geological methods by observations under the microscope, cutting thin sections etc. These methods are costly and time consuming. Samples are moved from the field to the laboratories for analysis.

Petro-physical evaluation is a better method, which involves the estimation of parameters that are of interest to the production of hydrocarbon from a reservoir, plays a major role by answering the questions of how porous, permeable, thick, and saturated with hydrocarbon a reservoir is. Also, the production of oil relative to water as well as the volume of oil in place and the life span of a particular reservoir can be estimated using information derived from petro-physical analysis.

Petro-physical evaluation offers a level of certainty since measurement are taken in-situ by means of wire-line geophysical logs. Therefore, the derived properties are truly characteristics of the lithologic units at the depths of measurements. However, integration of methods for the analysis of any prospect offers a greater level of certainty and confidence in the information there obtained.

\section{Materials and Methodology}

The data sets used for this work are:

- A base map

- Composite wire-line logs comprising the gamma ray, resistivity, neutron and density porosity and caliper logs.

The gamma ray log was used in the identification and mapping of lithologic boundaries between the permeable reservoir and non-permeable units of the study area. While the resistivity $\operatorname{logs}$ were employed for the identification of the hydrocarbon bearing zone, and for the determination of the porosities of the intervals of interest.

To derive the other reservoir parameters, such as fluid saturation, formation factor, permeability, etc., the combination of the information obtained were used either in cross-plots or empirical formulas.

\section{Results and Discussions}




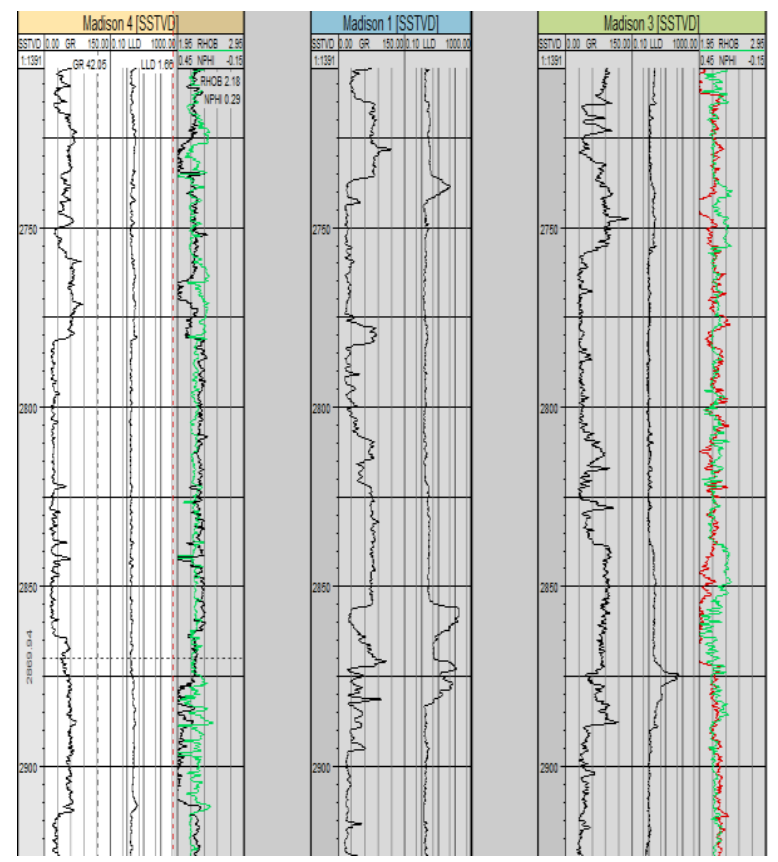

Figure 2: Logs for wells 1, 3 and 4

The raw data supplied for this work were in digital form and were plotted into analog form or graphical display in order to aid interpretation (figures 2). The well logs used in this study include Gamma Ray (GR), Resistivity Log (LLD), Neutron Porosity (NPHI) log and Bulk Density log.

\section{a. Litho-stratigraphic sequence}

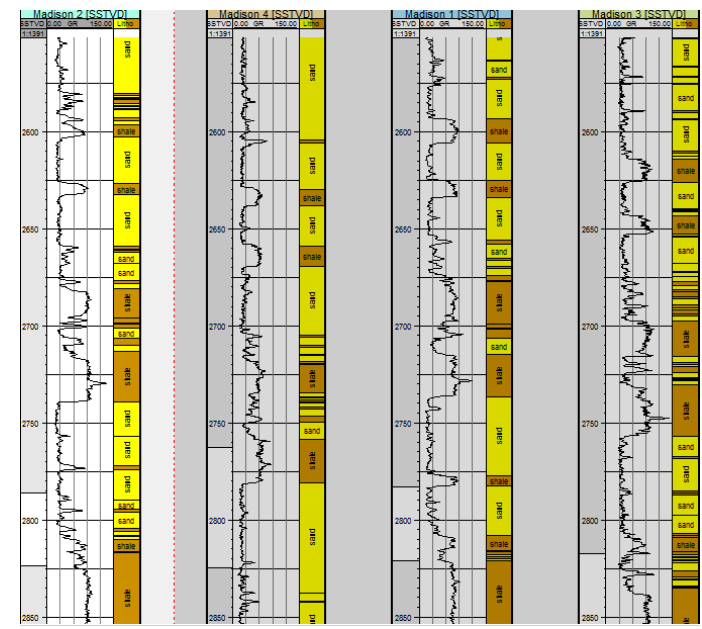

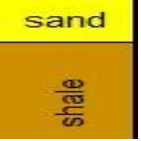

Figure 3: Litho-stratigraphic analysis of wells 1, 2, 3 and 4

The litho-stratigraphic sequence observed in the study area is an intercalation of sand and shale units. The shale layers are observed to increase with depth along with a corresponding decrease in sand layers. This pattern in the Niger delta indicates a transition from Benin to Agbada Formation. Figure 3 shows the interpreted stratigraphic sequence for the depth interval of interest which falls within depths of $1988.91 \mathrm{~m}$ to $2366.48 \mathrm{~m}$ for well 3 and $1988.05 \mathrm{~m}$ to $2389.37 \mathrm{~m}$ for well 4. The sand units that occur within this depth, their respective depth to top and bottom, net and gross thickness, porosity and other petro-physical data are thus presented in Tables 1 and 2 .

Table 1: The digitized and computed petro-physical parameters for well 3 


\begin{tabular}{|c|c|c|c|c|c|c|}
\hline \multicolumn{7}{|l|}{ WELL 03} \\
\hline \multicolumn{2}{|c|}{ PARAMETERS } & \multicolumn{5}{|l|}{ SANDS } \\
\hline & A & B & C & D & E & F \\
\hline TOP(m) & 1904.48 & 1997.05 & 2061.1 & 2098.67 & 2122.78 & 2261.5 \\
\hline BASE(m) & 1989.18 & 2047.53 & 2082.71 & 2118.59 & 2218.32 & \begin{tabular}{|l|}
2366.4 \\
\end{tabular} \\
\hline GROSS(m) & 84.7 & 50.48 & 21.61 & 19.92 & 95.54 & 104.9 \\
\hline $\mathrm{NET}(\mathrm{m})$ & \begin{tabular}{|l|}
60.56 \\
\end{tabular} & 26.82 & \begin{tabular}{|l|}
20.97 \\
\end{tabular} & 7.68 & 78.26 & \begin{tabular}{|l|}
68.74 \\
\end{tabular} \\
\hline NET/GROSS & 0.715 & 0.531 & 0.97 & 0.386 & 0.819 & 0.655 \\
\hline $\mathrm{I}_{\mathrm{GR}}$ & 0.31 & \begin{tabular}{|l|}
0.384 \\
\end{tabular} & 0.269 & 0.404 & 0.307 & \begin{tabular}{|l|}
0.336 \\
\end{tabular} \\
\hline$\overline{\operatorname{tat}}(\%)$ & \begin{tabular}{|l|}
10.1 \\
\end{tabular} & \begin{tabular}{|l|}
13.91 \\
\end{tabular} & 8.25 & 15.09 & 9.94 & \begin{tabular}{|l|}
11.35 \\
\end{tabular} \\
\hline$R_{\alpha}($ ohm-in) & 38.52 & 28.81 & 19.79 & 11.3 & 16.8 & 5.9 \\
\hline F & \begin{tabular}{|l|}
9.28 \\
\end{tabular} & 8.75 & 8.43 & 10.95 & 9.36 & 8.94 \\
\hline$R_{\text {s. }}$ & 0.115 & 0.122 & 0.127 & 0.18 & 0.114 & 0.120 \\
\hline$R_{0}($ ohm-in) & 1.62 & 1.62 & 1.62 & 1.62 & 1.62 & 1.62 \\
\hline Sows & 0.0681 & 0.0661 & 0.0649 & 0.074 & 0.0684 & 0.0669 \\
\hline Sund $\%)$ & 16.6 & 19.2 & 23.3 & 30.8 & 25.2 & 42.6 \\
\hline Sha) & 83.4 & 80.8 & 76.7 & 69.2 & 74.8 & 57.4 \\
\hline$S_{2 a}(\%)$ & 69.8 & 71.9 & 74.7 & 79 & 75.9 & 84.3 \\
\hline$\phi(\%)$ & 28.4 & 29.2 & \begin{tabular}{|l|}
29.7 \\
\end{tabular} & 26.3 & 28.3 & 28.9 \\
\hline
\end{tabular}

Table 2: The digitized and computed petro-physical parameters for well 4

\begin{tabular}{|c|c|c|c|c|c|c|}
\hline \multicolumn{7}{|l|}{ WELL 04} \\
\hline \multirow[t]{2}{*}{ PARAMETERS } & \multicolumn{6}{|l|}{ SANDS } \\
\hline & A & B & C & D & E & $F$ \\
\hline $\mathrm{TOP}(\mathrm{m})$ & \begin{tabular}{|l|}
1902.96 \\
\end{tabular} & \begin{tabular}{|l|}
1994.5 \\
\end{tabular} & 2061.82 & 2099.96 & 2127.23 & 2263.19 \\
\hline$\overline{B A S E}(\mathrm{~m})$ & \begin{tabular}{|l|}
1989.55 \\
\end{tabular} & \begin{tabular}{|l|}
2056.14 \\
\end{tabular} & 2091.94 & 2121.92 & 2240.65 & 2389.02 \\
\hline GROSS(m) & 86.86 & 61.64 & 30.12 & 21.96 & 113.42 & 125.83 \\
\hline $\mathrm{NET}(\mathrm{m})$ & 86 & \begin{tabular}{|l|}
59.08 \\
\end{tabular} & \begin{tabular}{|l|}
29.61 \\
\end{tabular} & 21.96 & \begin{tabular}{|l|}
104.3 \\
\end{tabular} & 110.92 \\
\hline NET/GROSS & 0.99 & 0.958 & 0.983 & 1 & 0.92 & 0.881 \\
\hline$\overline{\mathrm{I}_{\mathrm{GR}}}$ & 0.182 & 0.203 & 0.176 & 0.195 & 0.238 & 0.277 \\
\hline $\operatorname{Tha}(\%)$ & 4.95 & 5.65 & 4.72 & 5.39 & 6.98 & 8.57 \\
\hline $\mathrm{R}$ (ohm-in) & 51.98 & 46.19 & 26.51 & 24.9 & 26.11 & 8.54 \\
\hline F & 10.27 & 11.51 & 9.82 & 8.81 & 12.01 & 9.28 \\
\hline Ru & 0.158 & 0.141 & 0.167 & 0.135 & 0.175 & 0.134 \\
\hline $\mathrm{R}_{0}$ (ohm-in) & 1.07 & 1.07 & 1.07 & 1.07 & 1.07 & 1.07 \\
\hline Susos & \begin{tabular}{|l|}
0.0717 \\
\end{tabular} & \begin{tabular}{|l|}
0.0759 \\
\end{tabular} & \begin{tabular}{|l|}
0.0697 \\
\end{tabular} & 0.0664 & 0.0775 & 0.0681 \\
\hline Sinf\%) & \begin{tabular}{|l|}
17.7 \\
\end{tabular} & \begin{tabular}{|l|}
18.7 \\
\end{tabular} & 24.7 & 25.5 & 24.9 & 43.6 \\
\hline Sln $(\%)$ & 82.3 & 81.3 & 75.3 & 74.5 & 75.1 & 56.4 \\
\hline S.an $(\%)$ & 70.7 & 71.5 & 75.6 & 76.1 & 75.7 & 84.7 \\
\hline$\overline{\phi(\%)}$ & \begin{tabular}{|l|}
27.1 \\
\end{tabular} & 25.7 & 27.8 & 29.1 & 25.2 & 28.4 \\
\hline OMI & 0.250 & 0.262 & 0.325 & \begin{tabular}{|l|}
0.335 \\
\end{tabular} & 0.329 & 0.515 \\
\hline
\end{tabular}

\section{b. Correlation section}

The litho-stratigraphic correlation is a visual process which provides knowledge of the general stratigraphy of an area (Amigun, 1998). The correlation panel displayed in Figure 4 depicts the correlated section of the field. Observing the sequence, it was deduced that the lithologic units are consistent across the wells. Another feature that is noteworthy is the increasing trend in the thickness of the shale units with depth, which is indicative of transition into Akata formation. Within the zone of interest, a total of six reservoirs were delineated for all wells.

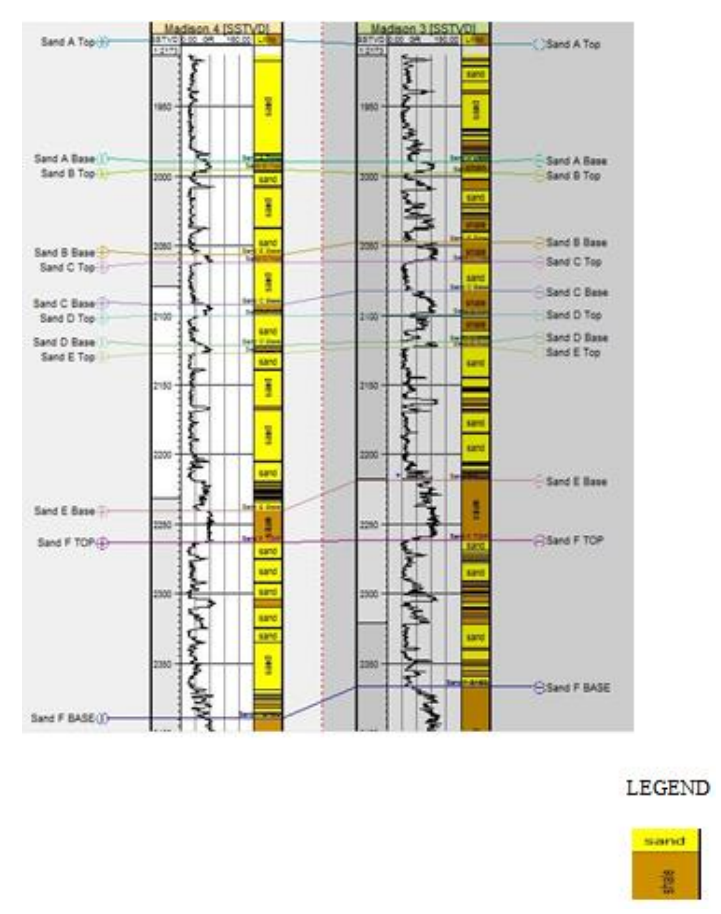

Figure 4: Correlation panel showing the typical subsurface bedding of the study area.

\section{c. Petrophysics}


Petro-physical parameter evaluation of "MADISON" field was carried out using digitized data gotten from the composite well logs provided. This was used to determine the Hydrocarbon saturation $\left(\mathrm{S}_{\mathrm{h}}\right)$ of each reservoir across the wells. All computations were done using relevant equations.

\section{SAND A}

Sand A is penetrated at depths (1904.48 - 1989.18) m and (1902.96- 1989.55) $\mathrm{m}$ by well 3 and 4 respectively. It is characterized by an average net sand thickness of (73.28 m) with a net sand to gross reservoir thickness ratio ranging from 0.715 to 0.99 . It has an average volume of shale $\left(\mathrm{V}_{\mathrm{sh}}\right)$ of $7.525 \%$, average porosity (Ø) of $27.75 \%$, average hydrocarbon saturation $\left(\mathrm{S}_{\mathrm{h}}\right)$ of $82.85 \%$, average absolute permeability (K) of $5943.46 \mathrm{md}$, average relative permeability to water $\left(\mathrm{K}_{\mathrm{rw}}\right)$ of $0.001305 \mathrm{md}$, average relative permeability to oil $\left(\mathrm{K}_{\mathrm{ro}}\right)$ of 0.7935 , average effective permeability to water $\left(\mathrm{K}_{\mathrm{w}}\right)$ of 7.58 , average effective permeability to oil $\left(\mathrm{K}_{\mathrm{o}}\right)$ of 4724.59md and average hydrocarbon pore volume (HCPV) of 0.2305 .

All the petrophysical parameters show that across the wells, good $\varnothing$, high $S_{h}$, good transmissivity with respect to oil (K, $\mathrm{K}_{\mathrm{ro}}$ and $\mathrm{K}_{\mathrm{o}}$ ), and high HCPV in the field. This reservoir is thus expected to be productive when put into production (Figures 5, 6 and 7).

\section{SAND B}

Sand B is penetrated at depths (1997.05 - 2047.53) m, (1994.5

- 2056.14) $\mathrm{m}$ by WELL 3 and 4 respectively. It is characterized by average net sand thickness of (42.95 m) with a net sand to gross reservoir thickness ratio ranging from 0.531 to 0.958 . It has its average hydrocarbon saturation $\left(\mathrm{S}_{\mathrm{h}}\right)$ to be $81.05 \%$. Shale volume in the reservoir in both wells 3 and 4 range from $13.91 \%$ to $5.65 \%$, with high porosity value of $29.2 \%$ and $25.7 \%$.

The average absolute permeability (K) value of $7494.65 \mathrm{md}$, average relative permeability to water $\left(\mathrm{K}_{\mathrm{rw}}\right)$ of 0.002095 , average relative permeability to oil $\left(\mathrm{K}_{\mathrm{ro}}\right)$ of 0.7615 , average effective permeability to water $\left(\mathrm{K}_{\mathrm{w}}\right)$ of 16.25 , average effective permeability to oil $\left(\mathrm{K}_{\mathrm{o}}\right)$ of $5687.725 \mathrm{md}$ and average hydrocarbon pore volume (HCPV) of 0.2225 is an indication that the reservoir will be productive, (Figures 5,6 and 7). .

\section{SAND C}

Sand C is penetrated at depths $(2061.1-2082.71) \mathrm{m}$, and (2061.82 - 2091.94) $\mathrm{m}$ by WELL 3 and 4 respectively. It is characterized by average net sand thickness of (25.29 m) with a net sand to gross reservoir thickness ratio ranging from 0.97 to 0.983

The reservoir has good hydrocarbon saturation which range from $76.7 \%$ to $75.3 \%$ in both well 3 and 4 respectively with water saturation $\left(\mathrm{S}_{\mathrm{w}}\right)$ of $23.3 \%$ and $24.7 \%$. The average absolute permeability $(\mathrm{K})$ value and average hydrocarbon pore volume (HCPV) of $8363.9 \mathrm{md}$ and 0.2185 is indicative of good productivity if set into production.

www.scirj.org

(C) 2020, Scientific Research Journal

http://dx.doi.org/10.31364/SCIRJ/v8.i9.2020.P0920803

This publication is licensed under Creative Commons Attribution CC BY. 


\section{SAND D}

Sand D is penetrated at depths (2098.67 - 2118.59) m and (2099.96 - 2121.92) $\mathrm{m}$ by WELL 3 and 4 respectively. It is characterized by an average net sand thickness of $(14.82 \mathrm{~m})$ with net sand to gross reservoir thickness ratio ranging from 0.386 to 1 .

The reservoir is characterized by moderate water saturation $\left(S_{w}\right)$ of $30.8 \%$ and $25.5 \%$ respectively for both well 3 and 4. The Hydrocarbon Pore Space is 0.182 and 0.217 respectively.

This reservoir is also productive looking at these parameters and all other parameters from the table 1 and 2 that cut across the reservoir, (Figures 5, 6 and 7).

\section{SAND E}

Sand E is penetrated at depths $(2122.78-2218.32) \mathrm{m}$ and $(2127.23-2240.65) \mathrm{m}$ by Well 3and 4 respectively. It is characterized by an average net sand thickness of $(91.28 \mathrm{~m})$ with net sand to gross reservoir thickness ratio ranging from 0.819 to 0.92 .

The reservoir in both wells is very prolific having high porosity (Ø) of $28.3 \%$ and 25.2 respectively with high average hydrocarbon saturation $\left(S_{h}\right)$ of $74.95 \%$, average permeability (K) of $4763.725 \mathrm{md}$, average relative permeability to water $\left(\mathrm{K}_{\mathrm{rw}}\right)$ of 0.00704 , relative permeability to oil $\left(\mathrm{K}_{\mathrm{ro}}\right)$ of 0.654 , effective permeability to water $\left(\mathrm{K}_{\mathrm{w}}\right)$ of 34.82 , effective permeability to oil $\left(\mathrm{K}_{\mathrm{o}}\right)$ of $3096.485 \mathrm{md}$ and average hydrocarbon pore volume (HCPV) of 0.2005, (Figures 5, 6 and 7).

\section{SAND F}

This sand unit cut across both wells also it varies in thickness from well to well, (2261.5 - 2366.4) $\mathrm{m}$ for well 3 and (2263.19 - 2389.02) $\mathrm{m}$ for well 4. It has average net sand thickness of $89.83 \mathrm{~m}$ and net to gross ratio of 0.655 and 0.881 for both well 3 and 4 respectively. It is characterized by low average volume of shale of about $9.96 \%$ and its permeability was estimated as 8136.07 md and 7071.24 md which can be described as excellent.

The sand unit is also characterized by moderately high water saturation $(42.6 \%$ and $43.6 \%)$ for both wells with averagehydrocarbon saturation of $56.9 \%$. Although it has its hydrocarbon movability index be 0.505 and 0.515 for both wells, which suggest that the hydrocarbon in the reservoir can be readily moved.

Considering the hydrocarbon movability index, water saturation and average hydrocarbon saturation it can be observed that this sand unit will not be as productive as other sand units across both wells, (Figures 5, 6 and 7).

\section{Average effective porosity}

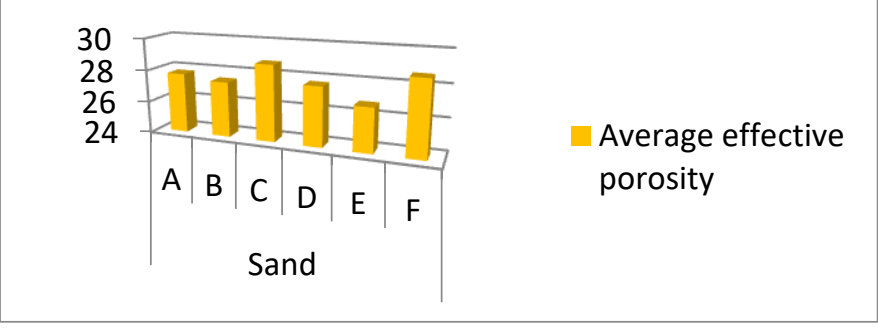

Fig 5: Bar chart showing average effective porosity. 


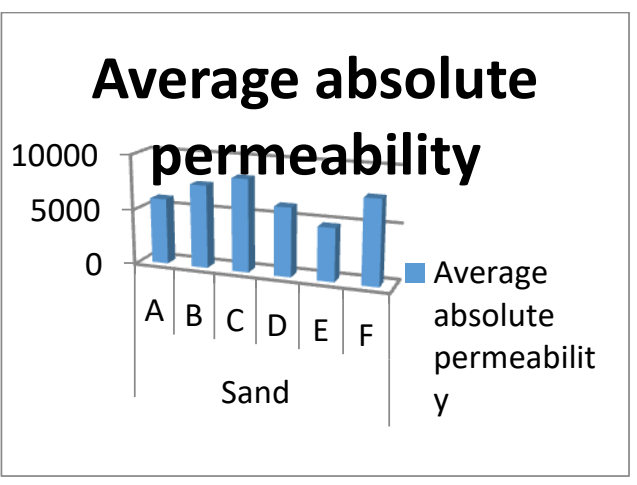

Fig 6: Bar chart Showing the average absolute permeability.

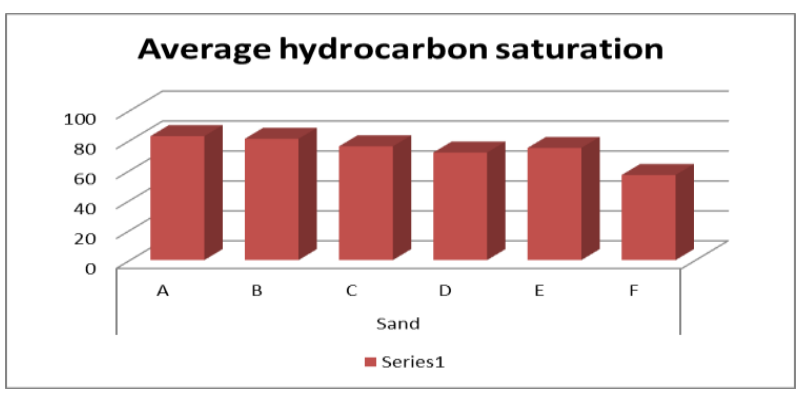

Fig 7: Bar chart showing the average hydrocarbon saturation.

\section{Conclusions}

In this study, the gamma ray log was used to define the lithologic units present in the "Madison" field, thus the stratigraphic sequence of the field was defined as the alternation of sand and shale units, which confirms that the field belongs to the Agbada Formation of the Niger Delta province. Observations made from the correlation of same lithologic show that they vary in thickness and depth from one location to the other within the field.

Through the use of resistivity logs, the hydrocarbon bearing interval lying within depths of $1988.91 \mathrm{~m}$ to $2366.48 \mathrm{~m}$ for well 3 and $1988.05 \mathrm{~m}$ to $2389.37 \mathrm{~m}$ for well 4 was identified and six sand units were delineated. These sand units (A-F) possess minimum hydrocarbon saturation of $56.4 \%$, and as such considered as hydrocarbon reservoirs. Each of these sand units extends through the field and they vary in thickness and shale content from one well location to the other. Their porosity estimated by means of density log was found to be in range of $25.2 \%$ to $29.7 \%$, while their permeability ranges from $2664.89 \mathrm{md}$ to $10184.26 \mathrm{md}$. Also the, the movability of hydrocarbons were derived and were considered satisfactory for the production of hydrocarbon, since the oil movability index fell below 0.7 .

In conclusion, the reservoirs (A to F) present at "Madison" field are considered to be good prospect.

\section{References}

[1] Amigun J. O., (1998): Interpretation of Seismic Reflection Data over Okpoko oil Field, Niger Delta; (unpublished M.Sc thesis) Obafemi Awolowo University, Ile-Ife

[2] Doust, H. and Omatsola, (1989): Niger Delta: AAPG Memoir 48 p. 201-238.

[3] Klett, T.R., Al brandt, T.S., Schmoker, J.W. and Dolton, J.L. (1997): Ranking of the world's oil and gas provinces by known petroleum volumes: U.S. Geological Survey Open-file Report-97-463, CDROM. 